\title{
Research of Learning Strategies in Flipped Classroom
}

\author{
Ximei Qu1 ${ }^{1}$, Rong Miao ${ }^{2 *}$ \\ ${ }^{1}$ Information Department, Zhejiang Open University, Hangzhou, China \\ ${ }^{2}$ Graduate School of Education, Peking University, Beijing, China \\ Email: Natasha210@126.com, ${ }^{\star}$ miao@gse.pku.edu.cn
}

How to cite this paper: Qu, X.M. and Miao, R. (2021) Research of Learning Strategies in Flipped Classroom. Open Access Library Journal, 8: e7398.

https://doi.org/10.4236/oalib.1107398

Received: April 9, 2021

Accepted: May 22, 2021

Published: May 25, 2021

Copyright $\odot 2021$ by author(s) and Open Access Library Inc.

This work is licensed under the Creative Commons Attribution International License (CC BY 4.0).

http://creativecommons.org/licenses/by/4.0/ (c) (i) Open Access

\begin{abstract}
In recent years, flipped classroom has been more and more popular in education field. The research studies learning strategies in an extra-curricular English teaching institution where the teaching model of flipped classroom is used. With qualitative research method, research objects are four students and a teacher in one class. After data analysis, the article gets three conclusions: Firstly, in flipped classroom, students' learning strategies are passive and not rich. Secondly, in flipped classroom, compared to face-to-face teaching, taking notes is better to be applied in online learning before class. And the realization of students' repeating learning needs the support of learning motivation and the supervision of parents. At last, in flipped classroom, teachers can practice teaching strategy of game-based teaching better. The research gives two implications: Firstly, Strengthen supervision and guiding role of teachers and parents in order to take advantages of flipped classroom better. Secondly, teachers should guide students to form their own learning strategies, and make a positive impact on students using their own teaching strategies.
\end{abstract}

\section{Subject Areas}

Educational Technology

\section{Keywords}

Flipped Classroom, Learning Strategies, Teaching Model

\section{Introduction}

Since the rise of flipped classroom in recent years in the United States, many Chinese schools and institutions have begun to practice this model. In Chongq- 
ing, Zhang Yujiang, an information technology teacher from Jukui Middle School, began to practice the teaching model of flipped classroom in 2011, and gradually explored flipped classroom of "four steps before class" and "five steps in class" suitable for his school. What's more, teachers from Changle No.1 Middle School in Shandong Province have also explored their own flipped classroom model. Professor Wang Qiong from Peking University has set up MOOC called "Flipped Classroom" on Chinese University MOOC 1 , with a total of 122984 people registered for seven phases. It can be seen that the flipped classroom has received a very high degree of attention in China. Different from traditional teaching method, in the flipped classroom, students complete learning the knowledge at home, and the classroom becomes a place of interaction, communication, collaboration and support among peers or from teachers.

The research tries to explore the students' learning process, behaviors and strategies, making field study in an extracurricular English institution where teachers are using the flipped classroom. The research first introduces the origin and definition of flipped classroom, and then introduces research dimension, research methods, research objects. Finally, discussion and conclusions are put forward. The research mainly tries to explore two points from the perspective of learning strategies: Firstly, what are students' learning strategies like in flipped classroom? Secondly, what effectiveness and impact can flipped classroom bring from the perspective of learning strategies?

\section{Origin and Definition of Flipped Classroom}

In the spring of 2007, Jonathan Bergmann and Aaron Sams, two chemistry teachers at Woodland Park High School in Rocky Mountain, Colorado, began to use screen recording software to record PowerPoint presentations and lecture sound, and upload videos to Internet to help absent students make up lessons. Later, these two teachers made students watch videos at home. And then at class, students could finish their homework, or teachers could explain questions to the students who have difficulties in learning in class. This kind of teaching model is widely welcomed by students. In order to help more teachers understand the concepts and methods of flipped classroom, they held "open house" of flipped classroom in Woodland Park High School on January 30, 2012, so that more educators and teachers could watch the operation of flipped classroom and students' learning state, which promoted the development of flipped classroom. The definition of flipped classroom is a new teaching model in which teachers provide learning resources in the form of videos in the informational environment, and students can complete watching and learning teaching videos and other learning resources before class, and then teachers and students complete homework, collaborative exploration, interactive communication and other activities together in the classroom (Zhong, Song \& Jiao, 2013) [1].

Teachers who use the tools and tutorials provided by Sophia website to carry ${ }^{1}$ https://www.icourse163.org 
out flipped classroom think that the mode of flipped classroom mainly refers to flipping the traditional homework, taking students' watching multimedia tutorials as homework, and using precious class time to complete tasks. At the same time, teachers liberated from classroom teaching can help students one-to-one deep understanding of the concepts (Newswire, P. R., 2012) [2].

Some scholars believe that in traditional teaching, teachers explain questions in class, and students understand deeply through homework after class; A new model is that students learn new knowledge after class and participate in in-depth understanding in class. This model is called flipped classroom (Lage, Platt, \& Treglia, 2000) [3].

This research refines the concept of flipped classroom in this paper as: Flipped classroom is a new kind of teaching model. In flipped classroom, teachers make teaching videos through the means of modern technologies, which consist of knowledge which they need to teach in class in traditional teaching, and students need to grasp the provided learning resources. While the face-to-face class is used to carry out questions, interactions, activities and further knowledge.

The reasons why flipped classroom has been widely concerned in the United States are the innovation of technology, convenient learning terminal, rich network resources and convenient network transmission environment. Secondly, because of the in-depth study of students' learning activities by educators and psychologists, they deny the simple teaching model of teachers' knowledge imparting and students' passive acceptance, and emphasize what students really master and their ability to apply knowledge, which promotes the rapid development of flipped classroom. Finally, the economic situation is also one of the important reasons for flipped classroom. Because the current economic situation in the United States does not allow the traditional large class teaching to be transformed into small class teaching. Flipped classroom can help save class time and allow teachers to have more time to guide students targetedly.

\section{Research Design and Implementation}

\subsection{Research Dimension}

Xuejing Wang (2009) [4] thinks that learning strategies are learning methods or learning plans to fulfill learning goals. The core of learning strategies is to choose the most effective method to achieve the learning goal and achieve the best learning effect according to the learners' characteristics, background and requirements. O'Malley \& Chamot (1990) [5] gives the classification of learning strategies in his monograph: repetition, grouping, summarizing and taking notes.

The above classifications are very enlightening, especially the dimension of "repetition". According to the theory of flipped classroom, one of the features of flipped classroom is that students can repeat learning the teaching resources provided by teachers after class. Therefore, this paper will consider the learning strategy of repetition. 
To a certain extent, the formulation and cultivation of learning plan can make students learn more directional and organized, and also can make students complete their learning tasks more efficiently, and know what problems they have and what needs to be focused on (Xing, 2021) [6].

Taking notes is an important learning strategy that runs through the whole classroom learning for senior grade students of primary school. It is a process of students' active construction of knowledge, which can improve students' learning (Sun, 2004) [7].

In summary, this study pays attention to the students' learning strategies in flipped classroom: making plans, taking notes, and repetition.

In flipped classroom, students need to have both face-to-face class and online learning after class. Therefore in the table of dimension, face-to-face class and online learning are both considered. According to the former theory foundation and analysis, dimensions of learning strategies will be classified into learning plans, taking notes and repeating, as shown below.

About Table 1, we need to explain two points: Firstly, in the model of flipped classroom, students can repeat learning knowledge online, so we add "repeating" the element in the Online Learning part.

Secondly, in addition to learning plan, taking notes and repeating, we want to try to find students' other learning strategies, so we add "other strategy" to leave some space for our findings.

We compile a classroom observation form and three interviews questions outline for students, teachers and parents respectively to collect relevant data.

\subsection{Research Methods}

In the qualitative research, researchers are used to take some unstructured interviews and direct observations. This paper is about learning strategies in flipped classroom, which is a kind of process research, and researchers need a long time to observe and communicate with research objects to get understanding of their situation, their thoughts and their behaviors, to get know of their change in the process. Therefore, qualitative research is very suitable for the research.

The researchers mainly carried out classroom observation to understand the performance of students and teachers in face-to-face classroom. At the same time, the students, teachers and parents were interviewed. Meanwhile, researchers took photos of students' notebooks.

\subsection{Research Objects}

The researcher field studies one extra-curricular English institution, which is

Table 1. Dimensions of learning strategies.

\begin{tabular}{cc}
\hline Environments & Dimensions \\
\hline Face-to-face Class Learning & Learning Plans, Note Taking, Other strategy \\
Online Learning & Learning Plans, Note Taking, Repeating, Other strategy \\
\hline
\end{tabular}


using flipped classroom model in teaching. We choose one class with four students (Their names are Jack, Lily, Quncy and Kitty) and their teacher-Ms Zhou. The four students correspond to the fourth grade in regular schools. They are around 10 years old.

\section{Discussion and Conclusions}

\subsection{Conclusions}

According to the data analysis, we get the following conclusions:

1) In flipped classroom, students' learning strategies are passive and not rich.

Through the previous data analysis, it can be found that learning strategies presented in the process of English learning are relatively not rich. Whether it is classroom learning or online learning after class, most of the learning strategies of primary school students are note taking. According to the classroom observation and interviews, there are not other obvious learning strategies found in the research process. No matter face-to-face learning or online learning, teaching activities are well conceived and designed by teachers which is maybe one of reasons why students do not apply the strategy of "making plans" in the learning process. They even have no concepts of "making plans". Learning is carried out passively with the modules of online learning system and teachers' teaching activities in face-to-face classroom.

2) In flipped classroom, compared to face-to-face teaching, taking notes is better to be applied in online learning before class.

In this study, when students learn online before class, teachers will put forward certain requirements of note taking, such as sorting out the words about colors on the antenna, or sorting out the new grammar. In the online learning, students are more convenient to pause the learning videos and take notes. However, in face-to-face teaching, teachers seldom guide students to take notes, but pay more attention to the consolidation of knowledge.

3) The realization of students' repeating learning needs the support of learning motivation and the supervision of parents.

From the perspective of theory, flipped classroom provides the chances of repeating learning for students. However, in practice, to fulfill repeating learning, learning motivation is needed.

We think that this is a very interesting conclusion. Because scholars generally believe that the model of flipped classroom can better help underachievers follow the learning pace, through the suspension and repeating learning. However, according to our observation, some of these underachievers' learning enthusiastic is not very high. When they learn online, they just finish the most basic tasks and don't spend time doing further study. About the tests provided to help check if they have mastered the knowledge point, they pay much more attention to the test scores than whether they have mastered the knowledge itself. In contrast, some of excellent students would make use of the advantage of repetition to grasp confusing points or get a higher score by way of retaking the tests to 
perform better to cover the lower score. Therefore, we believe that the teaching model of flipped classroom provides the conditions for repetition, but it is not certain to help students with learning difficulties to keep up with learning pace. In this condition learning motivation is a more important factor. If students lack intrinsic learning motivation, the advantage of repeating of flipped classroom can't do more.

4) In flipped classroom, teachers can practice teaching strategy of game-based teaching better.

During the process of research, the researchers did not find that students adjust or innovate some other strategies in flipped classroom. However, the researchers find that teachers have more time and energy to practice game-based teaching in flipped classroom.

Compared to the traditional teaching method, game-based teaching needs a period of time to carry out. But flipped classroom liberates teachers' time in class. Teacher Zhou interviewed in the research said, "we no longer need to spend most of our time explaining knowledge, so there is a lot of time to be liberated, and we can arrange some game activities. I received good feedback when designing these games, which also make me more confident to carry out game-based teaching." In face-to-face class, one of the most popular activities in this class is gaming time.

\subsection{Implications}

1) Strengthen supervision and guiding role of teachers and parents in order to take advantages of flipped classroom better.

The model of flipped classroom has given students a lot of free space, but self-control and learning strategies of primary students are not yet mature, and therefore they still need teachers and parents guide and monitor them.

For example, teachers can arrange some individualized learning tasks:

- Ask some students repeat watching the online learning resources;

- Take notes as their own needs and reward excellent students in note taking;

- In every face-to-face, students need to ask some questions they do not understand in the process of online learning.

Parents can also do something to help improve children's learning effects: They can help teachers monitor whether children finish their individualized tasks and make contact with teachers about children's performance at home.

2) Teachers should guide students to form their own learning strategies, and make a positive impact on students using their own teaching strategies.

Teachers should encourage students to form their own learning strategies in flipped classroom model, such as teachers should guide students to take notes according to their learning needs. In online learning, teachers guide students to write down knowledge points which are helpful to themselves and teachers will give students some incentives based on certain criteria.

In addition to proper guidance, teachers can also design more extensive teach- 
ing activities, and use their own teaching strategies to make an impact on students and take better advantage of flipped classroom.

As said previously, flipped classroom has freed teachers from constant speaking and explaining knowledge, so teachers can make better use of classroom time to use some teaching strategies such as teamwork and language applications, allowing students to collaborate, to express, to perform, to show, which must be a positive stimulus for students learning English. English learning is a process of long-term accumulation. As for the primary students, their strategy system is still not mature and teachers need to conduct and give suggestions to them, which will be an important step towards the future growth of the students.

Flipped classroom can bring surprises.

\subsection{Research Deficiencies}

The objects of this study are limited to a small scope-four students and one or two teachers are followed up and observed, and the research subject is limited to English. In follow-up research, more teachers and students can be observed and interviewed.

The researchers only observe the face-to-face teaching, but don't do the observation during students' online learning (researchers collect data interviews and platform data). This also leads to the research's being not rigorous.

\section{Conflicts of Interest}

The authors declare no conflicts of interest regarding the publication of this paper.

\section{Funding}

Research on the design of educational games to improve college students' mental health (XKT-QN014).

\section{References}

[1] Zhong, X.L., Song, S.Q. and Jiao, L.Z. (2013) Instructional Design Based on the Idea of the Flipped Classroom in ICT Environment. Open Education Research, 19, 58-64.

[2] Newswire, P.R. (2012) Sophia Survey Finds Student Grades Improve When Teachers "Flip" Their Classroom. MN-Sophia-Survey.

http://search.ebscohost.com/login.aspx?direct=true\&db=bwh\&AN=201205150900P R.NEWS.USPR.CG07132\&site=ehost-livehttp://search.ebscohost.com/login.aspx?di rect $=$ true $\& d b=b w h \& A N=201205150900 P R . N E W S . U S P R . C G 07132 \&$ site $=$ ehost-live http://search.ebscohost.com/login.aspx?direct=true\&db=bwh\&AN=201205150900P R.NEWS.USPR.CG07132\&site $=$ ehost-live

[3] Lage, M.J., Platt, G.J. and Treglia, M. (2000) Inverting the Classroom: A Gateway to Creating an Inclusive Learning Environment. Journal of Economic Education, 31, 30-43. https://doi.org/10.2307/1183338

[4] Wang, X.J. (2009) Research and Application of E-Learning Strategy. Master's Dissertation, Central China Normal University, Wuhan. 
[5] O'Malley, J.M. and Chamot, A.U. (1990) Learning Strategies in Second Language Acquisition. Cambridge University Press, Cambridge, 3-6.

[6] Xing, C.Y. (2021) Research on How Primary School Head Teachers Cultivate Students' Good Learning Habits. Love Science Every Day (Frontier of Education), 6, 155-156

[7] Sun, J. (2004) Theoretical Model and Practice of Taking Notes Research. Foreign Education Research, 8, 26-29. 